\title{
Requirements for the Article to be Published
}

$>14 \mathrm{pt}$

\section{Title (Times New Roman, 14 pt, Bold)}

$>14 \mathrm{pt}$

Ramune Ciarniene, Eimene Paulaviciene (Times New Roman, 12 pt, Bold)

$>12$ pt

Kaunas University of Technology (Times New Roman, 10 pt, Italic)

K. Donelaicio st. 73, LT-44029, Kaunas, Lithuania

e-mail: (Times New Roman, 10 pt, Italic)

$>6 \mathrm{pt}$

DOI(Times New Roman, 10 pt, Italic)

$>12 \mathrm{pt}$

Information layout and editing of the article

$>12 \mathrm{pt}$

Abstract (1500 printed characters, Times New Roman, 10 pt, Italic). The abstract of an article should be arranged in one column 10 pt. The text is written in English with 1 interval spacing. The article should be prepared by Microsoft Word text editor. The text should be laid out on A4 format $(210 \times 297 \mathrm{~mm})$ page with the following margins: top - $20 \mathrm{~mm}$, bottom $25 \mathrm{~mm}$, left and right $-18 \mathrm{~mm}$. Introduction (the scientific problem of the article, its novelty, aim, objective, research methods); Presented articles are assessed by two experts. References (not less than 25 resources applying APA format, wide use of ISI (http://www.isinet.com/isi/) and the list of cited research publications, e.g.:

Inzinerine Ekonomika-Engineering Economics, (all the references should be noted in the text of the article);

The summary in the Lithuanian language (9000 printed characters and not less than five key words);

A recommended volume of the laid out article is 5-6 pages prepared according to the requirements of the laid out format.

$>6 p t$

Keywords: not less than 5 in English (Times New Roman, 10 pt, Italic)

\section{$>14 \mathrm{pt}$}

\section{Introduction and Titles of sections (Time New Roman, 11 pt, Bold)}

$>6 p t$

The text of an article should be arranged in two columns $10 \mathrm{pt}$, with $6 \mathrm{~mm}$ spacing between them. The text is written in English with 1 interval spacing. Each paragraph should be started on a new line $(0.6 \mathrm{~cm})$. The

text revealing who has already dealt with the problem being researched in Lithuania and foreign countries and give the surname and the year of presentation (e.g., Ciarniene, 2008);

Table

The title of a table ( $9 \mathrm{pt}$, Bold)

\begin{tabular}{|l|c|c|c|}
\hline & Table information (8 pt) & Table information (8 pt) & Table information (8 pt) \\
\hline 1. & & & \\
\hline 2. & & & \\
\hline 3. & & & \\
\hline
\end{tabular}

Diagram layout and arrangement in an article

Information

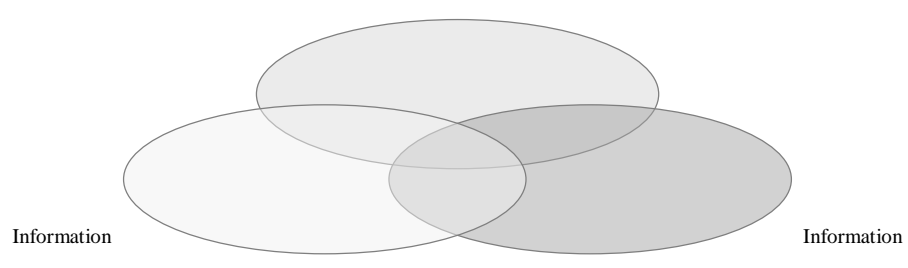

$>6 \mathrm{pt}$

Figure 1. Title (9pt) 
$>12 \mathrm{pt}$

\section{References: layout and arrangement}

$>6 \mathrm{pt}$

The list of references is presented in two columns (10 pt) according to the alphabet. The spacing between research publications is $3 \mathrm{~mm}$, the text is written with an interval spacing, e. g.:

Malakauskaite, A., \& Navickas, V. (2010). Relation between the Level of Clusterization and Tourism Sector Competitiveness. Inzinerine Ekonomika-Engineering Economics, 21(1), 60-67.

$>3 p t$

Tamosiunas, A. (2010). Managing Corporate Strategic Changes in the Context of Climate Change. Inzinerine EkonomikaEngineering Economics, 21(1), 19-31.

$>3 p t$

Zavadskas, E. K., Turskis, Z., Ustinovichius, L., \& Shevchenko, G. (2010). Attributes Weights Determining Peculiarities in Multiple Attribute Decision Making Methods. Inzinerine Ekonomika-Engineering Economics, 21(1), 32-43.

$>12 p t$

Ramunè Čiarnienė, Eimenė Paulavičienè $(8 \mathrm{pt})$

$>6 p t$

The title of the article in the Lithuanian language $(8 \mathrm{pt}$, Bold)

$>6 p t$

Summary in the Lithuanian language $(8 \mathrm{pt})$

$>6 p t$

Keywords: in Lithuanian (8 pt) 